\title{
Narco-Culture as a distortion of gender stereotypes: An aggravating factor in the situation of violence and conflict in society
}

La narco-cultura como una distorsión de los estereotipos de género: Un factor agravante en la situación de violencia y conflicto en la sociedad

DOI: 10.21803/adgnosis.v8i8.359

\begin{abstract}
Today, Narco-Culture has transformed many aspects in some society. One of the aspects still to be explored is linked to studies of gender stereotypes, because very little research has been done on this subject. For this reason, the main objective of this article is to explore how drug trafficking has distorted gender stereotypes, linking this viewpoint as an aggravating factor in situations of conflict and violence in society, taking Colombian society as a reference and yet it could be applied to other countries and contexts. Thus, the premise of the article is that the Narco-Culture has changed the role of men and women in society. The most significant findings show that the gender perspective provides a holistic view of the phenomenon of violence in society and can therefore help authorities to design effective public policies that break its cycle, Understanding also that society and culture have a great direct and indirect responsibility in the perpetuation of drug trafficking and all manifestations of violence.
\end{abstract}

Keywords: Narco-culture, gender stereotypes, violence, conflict.

\section{Resumen}

Hoy en día, la Narco-Cultura ha transformado muchos aspectos en algunas sociedades. Uno de los aspectos aún por explorar está relacionado con los estudios de los estereotipos de género, porque se ha hecho muy poca investigación sobre este tema. Por esta razón, el objetivo principal de este artículo es explorar cómo el narcotráfico ha distorsionado los estereotipos de género, vinculando este punto de vista como un factor agravante en situaciones de conflicto y violencia en la sociedad, tomando como referencia la sociedad colombiana y, sin embargo, podría aplicarse a otros países y contextos. Por lo tanto, la premisa del artículo es que la narco-cultura ha cambiado el papel de los hombres y las mujeres en la sociedad. Los hallazgos más significativos muestran que la perspectiva de género proporciona una visión holística del fenómeno de la violencia en la sociedad y por lo tanto puede ayudar a las autoridades a diseñar políticas públicas efectivas que rompan su ciclo, entendiendo también que la sociedad y la cultura tienen una gran responsabilidad directa e indirecta en la perpetuación del narcotráfico y de todas las manifestaciones de la violencia.

Palabras clave: Narco-cultura, estereotipos de género, violencia, conflicto.
Massiel Miranda Yanes ${ }^{1}$

massiel.miranda@campusucc.edu.co

Shanny Valdes Salas ${ }^{2}$

shanny.valdes@armada.mil.co

\section{Cómo citar este artículo:}

Yanes, M. \& Valdés, S. (2019). Narco-Culture as a distortion of gender stereotypes: An aggravating factor in the situation of violence and conflict in society, 8(8), p. 49-58. DOI: 10.21803/adgnosis.v8i8.359

1 Psicóloga de la Universidad Cooperativa de Colombia, Docente de la Escuela de Formación de Infantería de Marina, ORCID https://orcid.org/0000-0003-4484-5198

2 Docente de la Escuela de Formación de Infantería de Marina. 


\section{$\stackrel{\sim}{\infty}$ Introduction}

The drug trade as we know it today is a source of violence, either by the generated conflict between the various drug cartels, by the monopoly of the business. As a resource for illegal groups who use it as funding to sustain its war against the state, or simply by the amount of economic resources that surround this illegal activity to which many want to access.

When a society lives too long with this phenomenon, it ends up being permeated and transformed by the drug subculture. It is possible to observe a hyper masculinization represented in the figure of the "boss", whose economic power gives status, access to luxuries never imagined, women and a social position beyond the law, without much effort, neither much time spent.

Women suffer disempowerment, the figure of the woman who must meet certain stereotypes of beauty appears, which is more valued for their physical appearance than their intellectuality. Becoming a property or object associated with a loss of values that allows the appearance of stereotypes like the "mujer prepago" (prepaid) which is socially accepted.

To tackle the problem, it has been put into the orbit of national security. Others see it as a simple crime and even some aspects are considered public health problems, such as consumption; but few have tackled the phenomenon as a gender issue.

The problem arises from the rapid loss of values in a society promoted by drug trafficking and a culture of easy money, which places it as the ideal to be achieved, becoming a benchmark of success that ends up affecting gender roles.

This could explain why it is so difficult to re-socialize a person who has been immersed in this world, or even why many DDR programs fail in their reintegration phase of individuals to society, which end returning to these practices, purely and simply because there is no positive reference to reconstruct the masculinity of these individuals from another perspective, such a good job or financial remuneration. This makes the phenomenon of drug subculture inlaid in the society, becoming a multiplier of violence that constantly regenerates, deepening gender inequality and violence.

In this context, a theoretical and historical framework is proposed that will make it possible to understand how the gender issue has been linked to the illicit drug trade, with emphasis on the drug culture as a phenomenon, and from this perspective, the impact of this culture on gender stereotypes is considered, ending with an analysis of drug trafficking as a factor generating violence, from the point of view of gender, and from this point of view, some conclusions are proposed and discussions are held on the subject.

\section{Background Theory And History}

The use of coca leaves as traditional medicine has been linked to the customs and traditions of some indigenous peoples. Its use has been millenary and is shown as stated by (Cornell, 2007) that production of narcotics today, takes place in or near countries or regions where its local cultivation is linked to the culture and has been a tradition. Many indigenous communities in Peru, Bolivia and Colombia that are part of the Andean region have cultivated coca for centuries, as a tradition that is closely linked to their beliefs and culture.

The armed conflict taking place in Colombia has played a key role in creating conditions for the expansion of drug trafficking throughout the country. According to some scholars there is a direct relationship between illicit drugs and conflict (Cornell, 2007). Which is not only seen in Colombia, but it attracts the attention of researchers, being a pattern repeated in many of the conflicts which are active today in different regions around the world.

Explanation of the relationship between narcotics and conflicts, is given by the sociopolitical conditions that are generated during the conflict, where large rural areas become controlled by the rebel group and 
the state and its authorities have little or no presence (Cornell, 2007) secondly, the generation of high economic gains that benefit include not only the insurgent group that controls the territory and encourages the cultivation of narcotics on a large scale, but also the peasants who see in cultivation, one source of income that allows them to improve their living conditions.

Colombia has not historically been the largest producer of cocaine. Narcotics smuggling begins in the 70 s, with the so-called "fiebre Marimbera", which was a marijuana traffic destined mainly to the United States, and motivated by social movements happening at that time. Some authors argue that was influenced significantly by marijuana addiction which acquired US troops in the Vietnam War which increased consumption of marijuana upon returning home from the War (Atehortúa Cruz \& Rojas Rivera, 2014; Duarte, 2013).

However, the duration of marijuana trafficking was short, and by the end of 1977 it was replaced by cocaine, which was trafficked by the same networks of the Colombian mafia. At that time, the cocaine was purchased in Peru and Bolivia, being Colombia one place of transit to the United States.

In the 80s, drug traffickers began to implement the growth and production of cocaine in Colombia. Thanks to the aforementioned conditions, it expands significantly in many regions. Given this bonanza, during the late 80 s and early 90s, virtually all armed actors and many sectors of civil society were directly or indirectly involved in drug trafficking. Being the big cartels those who imposed the rules of the game, particularly as they were those with the capability to place the product on American streets (Cornell 2007; Atehortúa Cruz \& Rojas Rivera, 2014).

Therelationships and connections created between political actors, drug cartels, illegal armed groups of right and left wing, businessmen, traders and virtually all levels of society around the trafficking of cocaine, have been of unimaginable proportions (Echavarría, 2009; Cornell, 2007) and being a completely illegal and highly profitable business, the dispute over control of it, has generated high levels of violence in Colombian society, but was not been the only determining factor.

Violence in Colombia has been the subject of many studies, for example (Ramírez, 2002) argues that violence is due to a lack of hegemonic power by the state to structure the relations of power between it and citizens. Meanwhile (Camacho, 2002) supports previous argument and argues that the state gave in control of the territory to other legal and illegal actors which created power structures to their accommodation, consequently resulting increased rates of violence (Trujillo, 2005) argues that since the Catholic Church as an entity lost power and relevance within Colombian society in the past, there was no capacity from the state to assume that role of power and hegemonic leadership on society.

What can be deduced in the Colombian case is that, the inability of the state (Echavarría, 2009) to exercise authority, have the monopoly of violence and control territory, allowed the various illegal actors including those associated with the drug establish their own power relations by using violence, and this has been happening in the country during the 80's and 90's, even in the present (Atehortúa Cruz \& Rojas Rivera, 2014).

All this amalgam of actors and factors and the fact that they have remained so long in society and have been so violent, necessarily end up affecting the society itself. Affecting not only the most visible structures, but also all relationships and roles established to its members including gender roles, which in the case of drug trafficking are distorted by what has been called "the narco culture."

\section{Narco-Culture As A Phenomeno}

As its name says, the "narco-culture" is a lifestyle, which is tied closely to how the drug cartels and persons associated with them, have established a social order within the state (Duarte, 2013). "Narco-culture" is the result of the mixture of many social, economic and political factors and how the cartels have sought for its legitimation in society.

In many societies, there is a tendency to negatively 
stigmatize people who engage in drug trafficking (Cornell, 2007) but history in Colombia has been something different and there is a double standard in this regard. First there is a political discourse that seeks to delegitimize and demonize the "narcos" (Drug traffickers) and everything that is involved in the illegal trafficking of narcotics, but on the other hand, there is acceptance by society of certain practices and activities related directly to it.

Many scholars have studied this phenomenon, but the reality is that Colombia as a country with so many social inequities, drug trafficking has been seen as a form of social inclusion, a way in which many marginalized young people have been able to climb the social scale and get in a different way, all other means had not been possible, like recognition and social status, capital accumulation access to goods and services. Which in other words, is nothing more than a search for the realization of their masculinity, against the model that society has imposed (Duarte, 2013).

The problem lies in the "narco's mentality", because there is a tendency to live to the extreme, so the "narco-culture" is characterized by a world of excess and luxury, where everything has a price including people and you get to promote an extreme form of heterosexual masculinity (Cabañas, 2012) prone to promiscuity, where women are seen as an object of simple use and satisfaction of man.

Sustaining this lifestyle, requires high levels of violence, which becomes an end in itself, which ends up legitimizing socially (McMillan \& Paul, 2011). The value of human life is degraded and violence is used to shape power relations with others, leading to forms of association or fraternities (Anderson, 2006) style criminal communities called cartels.

All these factors are amalgamated with the values of an extremely patriarchal and conservative society (Penglase, 2010) like Colombian, and "narco" (Drug trafficker) becomes the ideal figure of the male (Pobutsky, 2013) that provides and protects and therefore the model to emulate
Taking all this in context it is possible to see how the narco-culture has permeated and helped build a set of social anti-values in young people, and they must shape and achieve their masculinity in this hostile environment characterized by lack of opportunities that only shows one way to achieve development of his masculinity, motivated by power relations where economic factor and violence play an important role (Brison, 1995; Peletz, 1994; Quintero \& Estrada, 1998).

The manifested above teaches us that everything becomes a matter of survival (Quintero \& Estrada, 1998) where young people sacrificed by themselves to achieve their identity and social status. And for this reason, appear the most exaggerated forms of hyper-masculinity, as a life of wealth, luxuries and women. Also, because in this "narco-world", life expectancy is substantially reduced and there is a tendency amongyoung people to think that it is better to live a few years as a king than a long life as a beggar.

All this culture has been enhanced by the different cultural and social events, such as music, soap operas, movies and books among many others (Pobutsky, 2013) showing the "narco" as a figure who can't be stopped and whose power allows him to get what he wants (Cabañas, 2012) situation which has spread this lifestyle within society, and in one way or another ends up legitimizing it.

\section{Methodology}

Aiming at exploring how drug trafficking has distorted gender stereotypes, linking this viewpoint as an aggravating factor in situations of conflict and violence in society, we propose a systematic review of the literature, based on the publication of scientific articles on digital platforms such as Scopus and Wos. By means of a scientometric study, we proceeded to choose articles, books and scientific Journals from the mentioned electronic databases, with high impact in the academia and the importance of the works by means of extensive citations, this is how later these investigations were analyzed and compiled in such a way that a theoretical and practical framework is presented that allows to present the subject under study. 
This systematic analysis allowed a theoretical and historical context built that allows the referencing of how the illicit drug trade can transform gender stereotypes in a society and from there propose findings that illustrate how the role of women can be changed in a society dominated by the illicit drug trade and finally propose some conclusions and discussions regarding this issue.

\section{Findings}

\section{Impact Of Narco-Culture On Gender Roles The Role of Narco-Culture in masculinity: Hyper-masculinity}

The way in which masculinity is manifested is relative and different from each culture (Connell, 2005). Same is the way how society demands proof of manhood in men. However, these manifestations as argued by (Barker, 2005) are strongly affected by factors such as poverty and the mass propaganda as TV (McMillan \& Paul, 2011). Which spread stereotypes of masculinity and femininity that should be well seen and accepted.

It is not easy for young men, to achieve social and economic status demanded by society, especially in an environment of deprivation and lack of opportunities (Moser \& Clark, 2001). It is precisely this scenario, which offers them another unconventional form of material incomes and sexual ascendancy through the use of violence and group membership to be part of the gangs and drug cartels.

Therefore, as argued by (McMillan \& Paul, 2011), what these young people seek in these hostile environments, is not only to redeem their masculinity but also reduce levels of victimization and vulnerability to which they are exposed, and therefore, they tend to exaggerate these manifestations of masculinity.

To understand how drug trafficking has helped shape gender roles especially in man, it should also be analyzed another concept which is the "hegemonic masculinity”.

A very accurate definition is given by (Messerschmidt, 2005) who argues "Hegemonic masculinity as the culturally idealized form of masculinity in a given historical and social setting. It is culturally honored, glorified, and extolled situationally-such as the broader societal level (e.g., through the mass media) and at the institutional level (e.g., in school) - and is constructed in relation to 'subordinated masculinities' (e.g., homosexuality) and in relation to women”.

But keep in mind that this "Hegemonic masculinity" varies depending on the culture, age and epoch among many other factors (McMillan \& Paul, 2011) also (Connell, 2005) in their studies, conclude that there are different ways in which man accepts or rejects the imposed cultural norm.

Thus, the drug trafficker, manipulating this figure, helps to redefine the concept of hegemony, showing himself as an example to follow (Cabañas, 2012). In studies made by (Baird, 2011) among youth in marginal sectors, clearly concludes that the "narco" and its lifestyle, are idealized as the figure of the man of success, who can achieve everything he wants, thanks to its economic power that allows them to have a dominant position, because the principal axes to measure success and supremacy of masculinity are economic and social power, represented on the social status and access to women (Montoya Tellería, 1998).

Finally, but no less important to better understand the role of drug trafficking and its influence on the definition of roles and genres in society, one must analyze the concept of hyper-masculinity.

Hyper-masculinity is the result of an exaggerated appreciation of the power of man (McMillan \& Paul, 2011) which leads to the devaluation of women and their attributes. In the case of the "narcos" this way of thinking leads to consider the women as a simple sex toy (Cabañas, 2012) and put others in a lower category to maintain hegemony. As stated by (Hume, 2009) when man falls into the category of hyper-masculinization, the biggest losers are women.

In the "narco-culture", it is common that hyper-masculinity is associated with sexual practices (Parker, 1991), and therefore the act of penetration 
defines gender role, that is who penetrates is the dominant and who gets penetration is the dominated. In this context, the more promiscuous the person is, more power and control exercised and, in that context, the homosexual is considered a lower category person who contradicts the cultural norm of the dominant male (Penglase, 2010).

Gangs or drug cartels have been very successful in exploiting the social vulnerabilities and displayed as the optimal route to reach manhood and enjoy a lifestyle that without being exempted of risks, it carries a world of rewards. In this propaganda, cultural manifestations have played an important role and show how events such as "narco-corridos" (musical style) and the "narco-novels" that tell the success story of people linked to drug trafficking are so successful and well received in popular culture (Duenas, 2008) which give an example of the dimensions of the phenomenon.

\section{The Role of Narco-Culture in Feminism: Di- sempowerment role of women}

If for men and their masculinity, drug trafficking has brought significant changes to the archetypes endorsed by culture, on the side of women have been unfortunate consequences in terms of loss of value and femininity, dramatically affecting their identity and values.

This section seeks to address some of the most visible manifestations of the power loss of the role of women in Colombian society, as a direct or indirect result of drug trafficking, clarifying that it is not a generalized situation and it has been changing over time.

In patriarchal cultures, the role of women is relegated to the home and the care of children. Has not been easy for women to open spaces for active participation in society despite the campaigns, laws and speeches of politicians. Like men, women living in the most deprived areas and lack of opportunities are the most vulnerable, but the reality is that any social stratum remains out of this scenario.

The woman's body has become an object for narco
(Cabañas, 2012), and as such the epitome of beauty has been molded to their liking, it is for this reason that cosmetic surgery and breast and hip augmentations, are one of the fastest growing major businesses in the country. Value of women depends on their physical appearance rather than their qualities and intellectual abilities (Robinson \& Paramo, 2007).

Having these physical attributes, allows them to reach their femininity, because they can easily access a good social position or being courted by the narcos, who are responsible for providing them with luxuries and meet their economic needs, both for themselves and for their families, especially in the lower classes of society.

Popular culture is recreated by sitcoms, films and books among others, this narco-world that lacks values and identities. For these reasons appear writings like "Sin Tetas no hay Paraiso" (no tits no paradise) (Cabañas, 2012) to mention just one example. This writing is about the struggle of a middle-class woman to excel in society by performing cosmetic surgeries that allow her to achieve the prototype of beauty that drug traffickers seek for in women in their community. This searching of beauty standards became the door that allowed women to show out ahead and leave behind a life of hardship and needs.

The phenomenon of plastic surgery, is a patriarchal form of taxation of man over woman's body, that emphasize the hegemonic gender construction of women as victims of an exclusionary social system, they have to go to their physical attributes for a chance to perform as a woman and as a person using her body to achieve what they want (Robinson \& Paramo, 2007).

"Mujeres prepago" are nothing more than a kind of socially "acceptable" prostitution in which mostly upper-class college girls, offering sexual services for exorbitant amounts of money. Based on the ideal of having luxuries and a high lifestyle, in most cases their families have the economic capacity to provide and meet their needs.

Moreover, for the large sums of money involved, 
whoever agrees to pay for these services are usually people with high positions in society or mostly drug dealers, which pride themselves of the capability to access this type of women who in many cases are recognized models and actresses. What is clear, is that if there is a fairly widespread tendency among young women offering these sexual practices, it is because there is a high demand for them.

They are actually few studies regarding this kind of prostitution, especially for the difficulty to access those involved, and because in their mind, doing so does not make them prostitutes. Most do only during the period of their study time in college, then when they graduate just continue their normal lives. Actually, the irony is that the younger are better paid, so in that world a woman of 21 years old does not have many expectations to follow that style of life.

Finally, the narco-world is considered a hegemonic masculine world, where women are less than a secondary (Pobutsky, 2013). Very few women who dare to challenge the established order and even less those that succeed in imposing and achieving a level of hierarchy within the mafia cartels.

It is so below the concept that women are considered for the narcos, then a trend among drug trafficking organizations is to feminize their opponents (Pobutsky, 2013) and exacerbate machismo and its practices within the criminal organization.

\section{Drug Trafficking and Narco-Culture As A Fac- tor Generating The Violence, Analyzed From The Point Of View The Gender.}

As argued by (Baird, 2011), opportunities for masculinizAs argued by (Baird, 2011), opportunities for masculinization is a process that is affected by economic conditions in which young people grow up. In an environment of deprivation, it is more difficult for young people to achieve the status that is socially and culturally demanded.

However, according to the opportunities provided by the environment, whether legal or illegal, people end up negotiating the way they can achieve this status, for this reason, the drug trafficking is presented as an illegal alternative, but validates to reach the masculinization.

This perspective allows us to understand better, the fact that regardless of the risks associated with drug trafficking and violence levels that characterize it, while continuing the lack of opportunities and poverty in society, there will be those willing to take the risk of getting involved directly in it (Cabañas, 2012). It is a survival issue.

In this context it is possible to understand that the experiences and actions of young people during their membership to illegal drug cartels are determined by the roles and identities assigned by society (Moser \& Clark, 2001) and in most cases, these manifestations are carried to the extreme, as a way of seeking legitimacy and recognition to others from the point of view of gender.

The ability of drug traffickers, is to recognize the problem mentioned above, and manipulate the discourses and social relations, altering the values (Penglase, 2010) and legitimizing their actions within society, whether by coercion or persuasion.

What the experts have analyzed is that the use of violence is legitimized itself as a form of construction of masculine identity values (Penglase, 2010) by the use of paralleling extreme violence with manhood (DaMatta, 2010). It is in this logic that we can understand why the high level of violence used by these organizations, because in practice the more violent the person is, it is considered more masculine.

This mindset among people within these organizations is what has caused so many egregious cases in Colombia of intolerance and brutality, where the life of a person has a price and is very low.

A major issue related to the above is that usually, it is becoming more common that young people begin to engage in criminal activities at an early age, which causes two problems. The first is that a person who 
grow up in these environments and has no more social references ends up becoming someone very cruel and violent who hates all established order; and secondly reserializing a person with this background is a very complicated and difficult task, especially because a young of 18-year-old may have been spent more than half of his life killing and involved in illegal activities.

Other experts argue values (Penglase, 2010) that violence is an instrument used to establish the relations of power and can be deliberately used to impose on others and to ensure not only access to the recognition of social status, but also to keep it at any cost.

Thus, individuals are living together all the time in environments with different types of violence, social violence, economic violence, political violence (Moser $\&$ Clark, 2001) which eventually ends up becoming an indispensable part of development of their personality and identity, creating vicious circles from which it is very difficult to escape. So, the process is repeated from generation to generation (Baird, 2011) and expands as new scenarios are colonized.

Drug cartels, become the mechanism that allows individuals to achieve social status demanded, showing the group membership as an expression of success and manipulating the discourse to legitimize the use of violence, which becomes a purpose to achieve a goal (Baird, 2011) which ultimately is nothing more than a justification to sustain at any price the status achieved and to establish power relations with others.

That is the trap of drug cartels, so long as there are scenarios of lack of opportunity and poverty, they will be present in the life of communities and within society as a generator factor of violence and legitimizes itself again and again, and that ultimately ends up being tolerated.

This legitimacy that society makes of violence, eventually becomes a double-edged sword, because indifference and insensitivity that people feel for what happen to others, is the same that others will feel when happen any eventually to them.

\section{Conclusions And Discussions}

A gender perspective provides a better understanding of the phenomenon of violence in society, and thus can help the authorities to design effective public policies that break their circle. Establish policies based on repression and use of force only served briefly as the forces that control the dynamics of violence are rearranged, which becomes a spiral that repeats over and over again.

On the other hand, the gender perspective also allows understanding the behavior of youth in violent environments which can help design plans that allow them to get out of these scenarios and allow them receive help and support as survivors of a hostile system, which indirectly attacks the problem and drug scourge.

Society and culture have much responsibility directly and indirectly in the perpetuity of drug trafficking and all manifestations of violence. The first can be modified through education and appropriate public policies and the second can be transformed through the establishment of values to cohere society through good practices of coexistence.

The media play a key role to legitimize or delegitimize the roles assigned by society to individuals, and help shape the expectations that society demands from its members, thus can be used to reinforce positive stereotypes and discourage the negative ones.

The problem with the media in Colombia, is that most are private businesses, and it is difficult to change certain types of information, when they seek emissions of content to be profitable economically, and most of these emissions usually reproduce or reinforce gender stereotypes negatively.

The state should regain the monopoly of force, discouraging the use of violence as a dominant factor in the power relations between citizens and fulfill their role of generating the necessary conditions for creating equal opportunities for all social classes to perform ideals and roles that society assigns to 
each gender. This allows the state to be the dominant power that constrains the one hand those who want to engage in illegal activities, and on the other hand encourages and provides opportunities for personal fulfillment in good ways.

\section{Referencias}

Anderson, B. (2006). Imagined communities: Reflections on the origin and spread of nationalism. Verso Books. ISBN: 0860915468, 9780860915461

Atehortúa Cruz, A. L., \& Rojas Rivera, D. M. (2014). El narcotráfico en Colombia. pioneros y capos. Historia y Espacio, 4(31), 169207. ISSN-e 0120-4661

Baird, A. D. (2011). Negotiating Pathways to Manhood: Violence Reproduction in Medellin's. Periphery. Journal of Conflictology, 3(1), 30-41. https://doi.org/10.7238/joc. v3il.1438

Barker, G. T. (2005). Dying to be men: Youth, masculinity and social exclusion. Londres, Reino Unido: Routledge Taylor \& Francis Group. ISBN: 0415337747.

Brison, K. (1995). Changing constructions of masculinity in a sepik society. Ethnology, 34(3), 155-75. https://doi. org/10.2307/3773820

Cabañas, M. (2012). Narcotelenovelas, gender, and globalization in sin tetas no hay paraíso. Latin American Perspectives, 39(3), 74-87.https://doi.org/10.1177/0094582X11434303

Camacho, A. (2002). Credo, necesidad y codicia: Los alimentos de la guerra. Análisis Político, (46), 137-150. https://revistas.unal. edu.co/index.php/anpol/article/view/80263

Connell, R. W.(2005).Masculinities. Berkeley, California, Estados

Cornell, S. E. (2007). Narcotics and armed conflict: Interaction and implications. Studies in Conflict \& Terrorism, 30(3), 20727.https://doi.org/10.1080/10576100601148449

DaMatta, R. (2010). Tem pente aí reflexões sobre a identidade masculina.Enfoques, 9(1), 1-23. http://www.enfoques.ifcs.ufrj. br/ojs/index.php/enfoques/article/view/104/0

Duarte, M. (2013). El cartel de los sapos illness, body, and nation. Latin American Perspectives, 41(2), 144-160. https://doi. org/10.1177/0094582X13509070 
Duenas, G. P. (2008). Amidst weed, dust and lead: A narcotour through Sinaloa in the work of Lenin Márquez, Journal of Latin American Cultural Studies, 17(2), 203-20. https://doi. org/10.1080/13569320802228054

Echavarría, A. J. (2009). "Doing Gender in the Midst of War: The Example of the Demobilization Process of Paramilitaries in Medellín, Colombia 2003-2007”. Peace Studies Journal, 2(2), 51-75.

Hume, M. (2009). The politics of violence: Gender, conflict and community in El Salvador. Hoboken, Nueva Jersey, Estados Unidos: Wiley-Blackwell.

McMillan, A. S., \& Paul, M. (2011). 'It was good to learn how to show affection': Central American men who reject hypermasculinity. Community: Work \& Family, 14(3), 367-82. https://doi.org/0.1080/13668803.2011.588050

Messerschmidt, J. (2005). Men, masculinities, and crime. In M. S. Kimmel, J. Hearn \& R. W. Connell (Ed), Handbook of studies on men \& masculinities (pp. 196-212). Thousand Oaks, California, Estados Unidos:SAGE Publications. http://dx.doi. org/10.4135/9781452233833.nl2

Montoya Tellería, O. (1998). Nadando contra corriente: Buscando pistas para prevenir la violencia masculina en las relaciones de pareja. Managua, Nicaragua: Editorial: Punto de encuentro.

Moser, C., \& Clark, F. C. (2001). Gender, conflict, and building sustainable peace: Recent lessons from Latin America. Gender \& Development, 9(3), 29-39. http://dx.doi. org/10.2307/4030626

Parker, R. (1991). Bodies, pleasures and passions. Sexual Culture in Contemporary Brazil, 49(3). https://doi.org/10.1086/ jar.49.3.3630500

Peletz, M. G. (1994). Neither reasonable nor responsible: Contrasting representations of masculinity in a malay society. Cultural Anthropology, 9(2), 135-78. http://dx.doi. org/10.1525/can.1994.9.2.02a00010

Penglase, B. (2010). The owner of the hill: Masculinity and drug trafficking in rio de janeiro, brazil. The Journal of Latin American and Caribbean Anthropology, 15(2), 317-37. http:// dx.doi.org/10.1111/j.1935-4940.2010.01088.x

Pobutsky, A. B. (2013). Peddling Pablo: Escobar's cultural renaissance. Hispania, 96(4), 684-99. http://dx.doi. org/10.1353/hpn.2013.0104

Quintero, G. A., \& Estrada, A. L. (1998). Cultural models of masculinity and drug use: Machismo heroin, and street survival on the US-Mexico border. Sage Journals, 25(1), 147. https://doi.org/10.1177/009145099802500107

Ramírez, W. (2002). ¿Guerra civil en Colombia? Análisis Político, (46), 151- 163. https://revistas.unal.edu.co/index.php/anpol/ article/view/80268

Robinson, R. \& Paramo, P. (2007). Juvenile prostitution and community rehabilitation: An exploratory analysis of beliefs and values. Journal of Community \& Applied Social Psychology, 17(3), 237-47.https://doi.org/10.1002/casp.914

Trujillo, E. B. (2005). Muertes violentas: La teatralización del exceso. Medellín, Colombia: Universidad de Antioquia. 